\title{
9 Exploring the political economy of coal
}

\author{
Insights from Turkey
}

\author{
Ceren Ayas and John Wiseman
}

\section{Introduction}

This chapter explores the political economy of coal plants and mining in Turkey and the impact of key political and social actors on coal investment decisions and trends. We begin by noting and exploring differences between the governments' direct and underlying objectives for maintaining and expanding coal investment. We then proceed to employ the actor-centered political economy framework, developed by Jakob et al (2020) and covered in Chapter 1, to examine the role and influence of key political and societal actors. We conclude with a discussion of the factors and dynamics with the potential to change support for coal mining and coal-fired power generation in Turkey.

There are two major reasons for focusing on Turkey as a significant site for understanding the current political economy of coal-based power generation. First, Turkey's planned capital investment in the coal power sector is the 6th largest in the world with about $20 \mathrm{GW}$ of capacity to be built in the coming years (Global Energy Monitor, 2021). Turkey's plans to continue to add new coalfired power capacity significantly differ from the goals and actions required at the global scale to achieve the emissions reduction and global warming targets mandated by the Paris Agreement. Second, Turkey provides an important case study example of the characteristics and dynamics of an industrializing country reluctant to phase out coal.

The power system of Turkey is characterized by an ongoing rapid increase in coal generation. The installed capacity of coal plants has increased substantially since 2012, the year officially declared by the government of Turkey as the 'Year of Coal'. The government of Turkey continues to maintain a strong political commitment to expanding coal plant investments (primarily lignite) in order to maintain and strengthen national security. Despite the commitment to expand coal plant investments, the realization rate of the plants remains limited. Many of these planned coal investments $(65 \mathrm{GW})$ have been canceled or shelved in the last decade (Global Energy Monitor, 2021). While the realization of new coal projects has been very limited, the phase-out of existing coal-fired power plants still remains extremely slow. This chapter, therefore, looks at the enabling and constraining factors behind coal mining and power generation in 
Turkey and explores the role of different public, private and civic actors in the decisions regarding the underlying objectives of the ongoing dependence of Turkey on coal.

The key drivers maintaining investment in coal-based energy and constraining an acceleration of the transition to nonfossil energy technologies in Turkey are primarily political. Evidence from interviews with diverse experience and knowledge of the coal industry in Turkey highlights a conflation between direct objectives, frequently stated by the current government as strengthening national security and the underlying objective of maintaining the legitimacy of the current regime. From this perspective, the ongoing dependence of Turkey on coal in Turkey is primarily driven by the current government goal of strengthening national security (by exploiting the country's lignite resources) and maintaining centralized political power. This latter objective also leads to a strong focus on direct financial incentives to both local and international companies designed to increase lignite-based coal generation. These pressures currently override factors with greater potential to steer the government toward decarbonization. These factors include the low calorific value of lignite; the limited business interest in investing in coal and tensions arising from the environmental, political and financial concerns of citizens and business incumbents.

The chapter is structured as follows. The 'Methodology' section discusses the methodology employed to collect and analyze the data presented in this chapter. The 'Context: the coal sector in Turkey' section presents a brief overview of the coal industry in Turkey. In the 'Results: political economy of coal in Turkey' section, we present the results from interviews and document analysis on the political economy of coal in Turkey. In doing so, we highlight the conflation of the government's stated objectives of supporting the coal industry and the underlying government objectives of maintaining the legitimacy of the current regime. The 'Discussion and conclusion' section provides a discussion of factors and dynamics with the potential to change support for coal mining and coal-fired power generation in Turkey.

\section{Methodology}

The research methodology employed in this research is informed by a qualitative single case study approach (Stake, 1995). We used qualitative semi-structured expert interviews as a method to achieve our research objective of exploring the underlying factors leading to strong government support for coal production despite growing evidence that power generation from coal and mining is economically uncompetitive. For the purpose of empirical data collection in Turkey, we operationalized the actor-centered political economy approach of Jakob et al (2020). We conducted semi-structured interviews with 22 key stakeholders via videoconferencing tools between the period of April and June 2020. The interview questions are presented in the online appendix. 
We categorize interview partners by actors groups, including societal actors operating on an international level ('si'), societal actors operating on a national level ('sn'), business and industry nongovernmental organizations that are representing both high- and low-carbon industries ('b') as well as political actors ('p'), also including experts within commissions in opposition parties. Note that our sample of interviewees does not include government authorities. While this is an obvious limitation of the research, we attempted to mitigate the lack of government officials in the interview process by incorporating official documents and strategies in the data analysis phase. The institutional clustering of the key informants that took part in the data collection process is as follows. The vast majority of the participants are working in civil society organizations (10), followed by think tanks (2), foundations (2), Business and Industry NonGovernmental Organizations (2), health platforms (2), academia (1), political party (1), lawyer network (1) and public professional organization (1). 11 of the key participants are societal actors operating on a national level, 7 of them are societal actors operating on an international level, 3 of them are business actors and 1 of them is a political actor.

We utilized primary data based on the key themes that emerged throughout the interviews as well as secondary data derived from official documents and gray literature. Regarding the contextual factors and key players, 328 vivos (data that puts emphasis on the actual spoken words of the key informants) and 62 umbrella themes emerged throughout the interviews. We have categorized these themes under 7 categories and reflected the emerging challenges and insights outlined in the 'Results: political economy of coal in Turkey' section.

\section{Context: the coal sector in Turkey}

This section gives a short overview of the coal sector and current trends. We then focus on the role of public and private institutions in governing and influencing decisions regarding the expansion of coal investments with a specific focus on the role of de facto, 'unofficial' key players in the public sector. For detailed information on the roles and the mandate of primary public authorities responsible for energy decisions and the primary private actors of coal investments that have been at the forefront in coal generation, see the online appendix.

\section{Coal industry state of play and trends in Turkey}

Coal has a significant share in the electricity generation mix of Turkey. 37.2\% of electricity generation is provided from coal $(16.7 \%$ from local lignite and hard coal), 30.3\% from natural gas, $19.7 \%$ from hydropower, $6.5 \%$ from wind, $2.6 \%$ from solar energy, $2.4 \%$ from geothermal and 1.3\% from other resources (Ministry of Energy and Natural Resources, 2019, Turkish Electricity Transmission Company, 2020). Coal imports have grown steadily over the last 
40 years and are used mostly for power generation (Eurocoal, n.d). They have increased from 19.5 Mtoe in 2012 to 24.3 Mtoe in 2019 (IEA, 2021). Half of the coal imports to Turkey are from Colombia, one-third is from Russia, 7\% is from the United States, $5.3 \%$ is from Australia and $4.2 \%$ is from South Africa (Eurocoal, n.d).

Turkey's energy system increasingly depends on coal.29 new coal-fired power projects with a capacity of $33 \mathrm{GW}$ are currently being planned (announced or permitted); in addition, two plants $(1.4 \mathrm{GW})$ are under construction (Global Energy Monitor, 2021). In addition to new coal, there are ongoing efforts to rehabilitate and privatize existing coal plants in order to prolong their lifetime.

As there is no plan to phase out coal in Turkey, existing coal-fired power plants are retired only very slowly once they reach the end of their lifetime. Commissioning of new coal-fired power plants, however, remains limited despite strong government support. New coal projects with a total capacity of more than 76 GW have been canceled between 2010 and 2020 (Global Energy Monitor, 2021). The interest of the private sector regarding coal mining also remains low despite the state's strong facilitative role. Out of more than $5 \mathrm{Gt}$ of total reserves that are proposed to be mined, only one tender call (Eskişehir Alpu basin) has been finally realized, which resulted in the postponement of the project due to the unavailability of offers (Greenpeace, 2020).

\section{Governance of the power sector and key players}

Turkey is in the process of privatizing its electricity market. In terms of ownership of generation assets, $64.8 \%$ of Turkey's total installed capacity is owned by private entities and $22.2 \%$ is owned by the state-owned enterprise, EÜAş (Electricity Market Regulatory Authority, 2019). The primary private actors driving coal investments at the forefront in new coal generation in Turkey are EnerjiSA, Cengiz Enerji, Limak, Eren Enerji, Aksa, Bereket, Konya Şeker, Ciner, Çelikler, Diler and İC İÇTAş (Kurçaloğlu, 2019). It is important to note that these same companies have been active in the recent rehabilitation, retrofitting and capacity increases of existing coal plants and mines. In terms of ownership of mines, two state-owned coal mining companies, the Turkish Coal Operations Authority and Turkish Hard Coal Enterprises, own 60\% of the lignite mines, whereas 203 million mt of reserves is owned by private players (GBR, 2018). Among the owners of lignite mines, Imbat Madencilik, Fernas Holding, Demir Export, Yapi Tek, Erdemir Madencilik, Bereket Holding and EMSA Enerji stand out in terms of the size of the assets. Detailed information on the biggest private operators of power plants in Turkey is provided in the online appendix.

Stakeholders interviewed for this study frequently mentioned the Presidency of Strategy and Budget and the Turkey Wealth Fund (TWF) as the most influential players driving coal policy and investment decisions in Turkey [sn4, si4, si7, sn8; 11 mentions]. The influence of these agencies extends beyond their formal energy-specific mandate to encompass high-level strategic guidance to facilitate investment decisions. These institutions play a key facilitative role in 
utilizing new coal reserves on behalf of the private sector.The governance scheme for the new domestic lignite mines, for example, involves transferring coal reserves to the private sector with obligations consistent with a build-operate model (Ministry of Energy and Natural Resources, 2019). The Presidency of Strategy and Budget is responsible for contributing to the processes of policy and strategy development, investment programming and regulation of energy and mining markets. The Turkey Wealth Fund Energy (TWF Energy) formed in April 2020 is the responsible authority for strategic energy investments in Turkey and has an official mandate to utilize local resources in electricity generation. TWF currently owns the two largest power generation and distribution companies. This corresponds to the ownership of $27 \%$ of power assets in Turkey.

Since the fund owns power assets, it is not clear how TWF Energy functions as both a fund and a utility and how it differentiates from the existing stateowned enterprise, Electricity Generation Company (EÜAŞ). Moreover, the role of the state fund/utility in ensuring the operation of liberalized markets with transparent financial flows remains ambiguous. As one interviewee noted, these blurred roles have important governance and accountability implications.

Public economic enterprises are subject to Court of Accounts audits, or parliamentary scrutiny. I mean they are subject to public scrutiny unlike the Wealth Fund. I mean you can take action; you have executive power, but no one can audit you. So, it turns into a weird beast that is exempt from scrutiny.

It is also important to note the significant involvement of President Erdogan and his son-in-law (the former Minister of Energy and Minister of Treasury and Finance) in these organizations. This can be read as yet another reflection of the concentration of decision-making in the Presidency during the last decade.

The key private sector players in the energy industry in Turkey play a significantly different role from private sector energy companies in countries that depend on coal exports such as Australia or rely on local coal resources such as Germany and Poland. Given that there is no major private sector involvement in mining (lignite or hard coal), the private sector does not actively lobby to keep those assets.

\section{Results: political economy of coal in Turkey}

This section addresses the objectives leading to the maintenance of strong government support for coal production. Despite growing evidence that power generation from coal and mining is increasingly economically uncompetitive, reliance on coal helps to achieve outcomes that further some underlying political objectives that are only indirectly linked to energy policy. The most important underlying objectives in this regard are safeguarding national security and maintaining political control and legitimacy of current regime. Energy 
Table 9.1 Underlying and direct objectives of new coal generation in Turkey

\begin{tabular}{|c|c|c|c|}
\hline Underlying objective & $\begin{array}{l}\text { Direct energy } \\
\text { policy objective }\end{array}$ & Aspects & $\begin{array}{l}\text { Number of } \\
\text { mentions in } \\
\text { the interviews }\end{array}$ \\
\hline $\begin{array}{l}\text { Maintain and } \\
\text { strengthen } \\
\text { national } \\
\text { security }\end{array}$ & $\begin{array}{l}\text { Energy } \\
\text { security }\end{array}$ & $\begin{array}{l}\text { Decrease reliance on imports } \\
\text { Reduce foreign debt } \\
\text { Decrease political dependency on } \\
\text { non-NATO allies }\end{array}$ & 15 \\
\hline \multirow{3}{*}{$\begin{array}{l}\text { Maintain political } \\
\text { control and } \\
\text { legitimacy of } \\
\text { the current } \\
\text { regime }\end{array}$} & Private profit & $\begin{array}{l}\text { Ensure favorable operating } \\
\text { environment for business } \\
\text { incumbents }\end{array}$ & 57 \\
\hline & Employment & $\begin{array}{l}\text { Ensure jobs and working } \\
\text { environment for blue-collar } \\
\text { workers }\end{array}$ & 36 \\
\hline & $\begin{array}{l}\text { Environment } \\
\text { and health }\end{array}$ & $\begin{array}{l}\text { Minimize public resistance } \\
\text { concerning vulnerabilities from } \\
\text { coal (pollution, expropriation } \\
\text { and land degradation of habitats) }\end{array}$ & 178 \\
\hline
\end{tabular}

policy is used as a way to further these objectives by means of safeguarding energy security, securing private profit for the coal and construction industries, creating employment as well as (mostly local) environmental considerations. Table 9.1 provides a summary of the underlying objectives of new coal generation derived from official documents (i.e., statements in government plans and strategies as well as policy and regulatory frameworks) as well as evidence from interviews.

The number of mentions by societal, business and political actors provides insights on which actors prioritize the respective objectives. The objectives of national security and political legitimacy are of prime importance to government and public authorities. This includes decreasing reliance on imports, reducing foreign debt, decreasing political dependency and ensuring jobs. Private sector actors are primarily interested in maintaining profitably and a favorable operating environment. Civil society is more strongly focused on addressing the vulnerabilities that arise from coal. The dynamics and interrelationships of these objectives are discussed in more detail below.

\section{Energy security}

In the context of Turkey, energy security is formally tied to national security. Energy security cannot be understood in isolation from political and economic security. Turkey has tied its political trajectory to a vision of coal-based technological development. Increasing the dependence on coal has political and economic security aspects along with energy security. Turkey's approach to coal mining and coal-fired generation is rooted in a strategy to reduce dependence on imported natural gas and imported coal (IEA, 2021). Coal is portrayed as 
contributing to national (not only energy) security for the reasons of decreasing reliance on imports, reduce political dependence on other countries (specifically Russia) and reduce foreign debt. Coal investment priorities outlined in key government policy documents include maintaining national security, including through decreasing reliance on imports, reducing foreign debt and decreasing political dependency on non-NATO allies (Electricity Market Regulatory Authority, 2019, Presidency of the Republic of Turkey Investment Office, 2018). As noted above, coal imports to Turkey continue to rise despite encouragement of domestic lignite production. While this trend has been partially driven by a desire to reduce dependence on gas imports, it also reflects the fact that energy from domestic lignite production has been insufficient to meet rising energy demand.

According to the 2019-2023 Strategic Plan (Ministry of Energy and Natural Resources, 2019), the official overarching goals of the energy sector are: to ensure the security of supply, increase energy efficiency, strengthen institutional and sectoral capacity, increase regional and global activity in the energy sector and natural resources, technology development and localization, increase the predictability of the market; and increase the production capacity of the mining sector in a sustainable way.

Regarding the theme of energy security, the topics of reducing debt through decreasing energy import dependency and bolstering national security through decreasing political dependence emerged throughout the interviews [si3, si4, sn 2 , sn 3, sn 4, sn6, sn11; 15 mentions]. Among these subthemes, the preference on strengthening local coal production to decrease reliance on imports and balance the current account deficit and decreasing political dependence on non-NATO allies stands out.

As a result, the current government has been framing the decision to expand investment in coal as part of a strategy of 'localization in energy policy'. Renewables are discussed in a similar manner in addition to coal investments (within the official 'localization' policy of Local and National) whilst noting their intermittency and flexibility 'issues'. In other words, the role of renewables is subsidiary rather than substitutive (Foundation for Political, Economic and Social Research, 2019). This vision is operationalized through significant financial incentives and support for local coal-based industries. The state provides an enabling environment for new coal investments by maintaining policy and regulatory frameworks that encourage new coal investment and strengthening investor certainty through purchase guarantees for lignite. This is secured through subsidies and feed-in tariffs. Lucrative incentive packages are provided by the government to support the financing of new coal investments. These incentives are designed to stimulate build-operate or build-operate-transfer projects as public-private partnerships.

Turkey has also implemented a wide range of policies designed to support the development of lignite projects by subsidizing power plant capital expenditures as well as operating costs for lignite mines (Algedik, 2015, 2017). In 2015, a sum ofTRY 9 million (USD 1.1 million) was directed to fossil fuels, including coal, 
natural gas, oil and its derivatives in the form of tax incentives (Ateş and Acar, 2020). A feed-in tariff for lignite has been introduced in 2017 to secure the financial viability of mining operations. The government introduced 35 years of operating rights, 15-year power purchase guarantees and exemptions from future-proof carbon taxes and fees to provide a favorable investment environment. Exempting coal investments from additional burdens such as a carbon tax also serves this aim. Tax reductions, social security premium support, interest support and VAT exemptions are in place. Coal investments receive indirect financial support through the exclusion of these new investments from environmental legislation (Gümüssel and Gündüzyeli, 2019). Additional information regarding the policies that support coal over other energy sources is provided in the online annex.

\section{Private profit}

The objective of 'private profit' incorporates the need to accommodate the interest of the private sector in order to maintain the legitimacy of the current regime. Our analysis demonstrates that the key private companies in Turkey leading the development of the next generation of energy investment do not have a historical vested interest in coal-based technologies and tend to have a diverse portfolio of low and high carbon technologies. The major private players benefiting from new coal generation - Cengiz İnşaat, Kolin, Limak and Kalyon - stem from the construction sector (Oxford Business Group, 2015). For this reason, the level of government support needed to encourage coal investment by these firms in Turkey is high. Key energy companies are active in many large-scale construction projects facilitated by the government, including bridges, highways and telecommunications (see Graph Commons, 2015 for a full list of interactions of the private sector and the government in large-scale infrastructure projects in Turkey; see Europe Beyond Coal, 2020 for coal plant privatizations).

The close entanglement between the government and the private sector is demonstrated by the fact that construction companies curry political favors that involved losses in coal-related activities in exchange for lucrative deals in other sectors [sn1, si4, si7, b2; 5 mentions]. This is reflected in one of the interviews as

From time to time, they feel, or have felt, obliged to go into unprofitable ventures. The best example for this [...] is that Konya Şeker, Pankobirlik, bought the Sivas Kangal thermal plant. Because this has nothing to do with their usual business and they are constantly losing money. Apparently, they had to do this because of political concerns, I mean political coercion. Erdoğan apparently said to Konak,' 'You need to buy this. And you need to bid at this price.' So, they bid for it at that price, etc. Anyway, that's why most of these people are there. They adopt this approach; 'Whatever happens here, stays here'. 
Ensuring a favorable operating environment for business incumbents emerged as an important subtheme of maintaining political control and legitimacy of the current regime [si1, si3, sn1, si4, sn2, p1, sn3, si5, sn4, si6, sn5, sn6, si7, b1, b2, sn8, b3, sn11; 57 mentions]. See Paker (2017) for a detailed analysis on 'politics of serving' that elaborates on the megaprojects of the AKP as a tool of hegemony building. This mandate emerged with AKP in opposition to the politics of identity or wardenship in the neoliberal reorganization of the state. This mandate is based on offering large-scale infrastructure projects as services regardless of their social and ecological costs. Adaman, Arsel and Akbulut (2017) argue that the construction and energy sectors reproduced the existence of the state by their relatively low-level requirement of human capital and technical know-how whilst having a quick turnaround on capital outlays. The conceptualization of 'infrastructural moment' coined by Bridge, Özkaynak and Turhan (2018) to characterize the ramping up of energy infrastructure as a means of advancing the material interests of specific actors that are in control of the construction sector. This is reflected in one of the interviews as

What we call the state or the ministry is, in fact, a public reactor; what we call people are the public itself. These two [actors] clash on the basis of an unbalanced power dynamic; a public actor acts on behalf of a private sector actor, and extends and strengthens the latter's rights at the expense of the public, assuming the task of managing all these rights on behalf of the private sector.

The relationship between business incumbents and the decision-making authorities is mostly assessed as a criticism related to authoritarian decisionmaking practices. The relationship between incumbent companies and the President, the vested interests of the companies, issues regarding corporatist decision-making, and the protection of private interests by public authorities and issues regarding the late privatization of the assets are reported within this subtheme. Involvement of the private sector in renewable technologies alongside their coal investments (enabling a shift from coal to renewables) is mentioned as a potential enabling environment for transition specifically by the participants representing the business community. To give an example, the state has granted the construction of three utility-scale projects (coal, solar and wind) to one company that is active in construction sector (Kalyon Holding) in 2017 and ensured a purchase guarantee for each of these projects. This is reflected in one of the interviews as

We did privatize coal-fired thermal plants, but we did it with certain oligarchic capital-owners, such as Kolin, Limak, Çelikler, Bereket Energy, etc. that have close relations with the government. This was also the case for renewable energy. Certain subsidies were provided for renewable energy, 
such as YEKDEM, and YEKA. But these have always been intended for a small circle [of investors].

\section{Employment}

The underlying objective of 'employment' incorporates the employment structure of the coal sector along with the jobs that are negatively impacted by new coal investments. Coal-based industries are playing a declining role in maintaining employment in Turkey. The employment structure of the coal sector in Turkey is significantly different from other coal-dependent countries with stronger coal phase-out and just transition agendas in three ways. First, the number of workers in incumbent coal-dependent industries in Turkey has already been in steady decline without a phase-out policy. Second, the added value of the coal sector is not decisive in the overall employment structure and continues to lose its importance. Third, the working conditions of workers in the coal industry in Turkey are already poor due to a lack of unionization and extensive use of subcontractors. The unionization rate in the mining sector has steeply diminished. While the overall unionization rate was $67 \%$ in the mining sector in 2003 , it fell to $19 \%$ by 2015 (International Labour Organization Office for Turkey, 2016: 52). This situation allows casual, short-term working conditions that limit the capacity of mine workers to form a strong constituency with political power. In short, the coal trajectory in fact provides poor employment prospects. This trend is further intensified by the limited employment opportunities arising from the disruption caused by coal mining to the agricultural mode of production. Detailed information on the employment structure and vulnerabilities associated with coal plants and mining is provided in the online appendix.

The goal of maintaining and creating employment opportunities for bluecollar workers emerged as an important subtheme of maintaining political control and legitimacy of the current regime [si1, si3, sn1, si4, sn2, p1, sn3, sn4, si6, sn 5, sn6, sn8, b3, sn11; 36 mentions]. This theme includes reference to the employment vulnerabilities of the agricultural and mining sectors as well as the employment opportunities of renewable technologies. The vulnerabilities associated with employment in the agricultural and mining sectors and the employment opportunities of renewable technologies are frequently noted [si1, si3, sn1, si4, sn2, p1, sn3, sn4, si6, sn5, sn6, sn8, b3, sn11, 36 mentions]. The vulnerabilities regarding employment are not only understood as the occupations related to coal, but also the potential exacerbation of the mean of the existence of the local communities who rely on agricultural production. The change of working profile from agricultural worker to miner or blue-collar worker in coal plant operations due to expropriation of agricultural land emerged as a significant theme throughout the interviews.

\section{Environment and health}

The underlying objective of 'political power' incorporates material, social and political costs of new coal investments and citizen concerns based on these 
vulnerabilities. Coal plants pose a significant threat to public health and are an important contributor to air, water and soil pollution in Turkey. Minimizing public resistance concerning vulnerabilities from coal is premised on the need to maintain political control and legitimacy of the current regime. This theme is widely reported throughout the interviews. Pollution, expropriation and land degradation of habitats are listed among the most prominent vulnerabilities driving public resistance [si1, si3, sn1, si4, sn2, p1, sn3, si5, sn4, si6, sn5, sn6, si7, b2; 178 mentions].

Empirical evidence reveals that citizen concern is growing due to the risks and impacts of coal-based power generation and coal mining in Turkey. The public awareness of climate change in Turkey is quite high. The majority of the population is concerned about climate change, $75 \%$ according to the analysis conducted by İklim Haber and Konda (2018) and 76\% according to the IklimIN project (2018) conducted by the Ministry of Environment. Only $5 \%$ of the society supports coal power plants (İklim Haber and Konda, 2018). Çarkoğlu (2017) demonstrates that environmental concerns occupy relatively little space in party politics and there is a clear reflection of a partisan divide that shapes how the masses react to these concerns. Legal litigations against coal investments are increasing (Özlüer et al., 2018) so as the local- and nationallevel civic resistance (Environmental Justice Atlas, n.d).

Air quality is seen as an important driver of closure of coal plants as well as contesting new coal investments [si1, si3, sn1, si4, sn2, sn4, sn6; 14 mentions]. The presidential decision to close six plants in January 2020 is regarded by many as being influenced by public concerns over the health impacts of coal mining and combustion. Empirical evidence also shows the willingness of the NGOs in continuing their campaigns and legal litigation in contesting new coal plants and mines in Turkey. Local citizen groups in Amasra, Hatay, Bursa, Eskişehir and Adana are mobilizing to oppose new coal plants (Global Energy Monitor, n.d). See Turhan, Özkaynak and Aydın (2019) on historical transformation of grassroots mobilization and political engagement through the case study of Aliağa. Throughout the interviews, the impactful work on the NGOs was noted [si1, si2, si3, sn1, p1, sn5, sn7, b1, b2, sn8, b3, sn9, 32 mentions] and along with their catalyzer role on halting coal plants [sn2, sn 3 , sn 4 , si6, sn5, 17 mentions]. In contrast, some respondents stated the need for improvement of the civic efforts [si3, sn1, si4, sn2, sn3, sn6, 19 mentions]. These factors are influential in the increased material, social and political cost of the coal-based vision and decline in the realization of the actual plans despite the strong state support.

\section{Discussion and conclusion}

Turkey has tied its political trajectory based on a vision that currently stabilizes the coal regime. The key drivers in maintaining investment in coal-based energy and constraining the acceleration of the transition to nonfossil energy technologies are in fact primarily political. Our analysis shows that this vision provides ways for political control to be maintained. Hence, the underlying 
objectives that the coal-based trajectory depends on are primarily based on maintaining political control and legitimacy of the current regime that include political ties up to the highest level of the government.

Contrary to these objectives, the 'coal rush' meets with a reality where the underlying objectives are in tension with the coal trajectory. A number of factors have the potential to reduce official support for power generation from coal mining and coal-fired power generation in Turkey. These factors create a potentially strong enabling environment for Turkey to accelerate an equitable and orderly phase-out of coal as well as halting new coal investments. Contrary to political will to increase the share of coal in power generation, the supporters of the ongoing dependence of Turkey on coal are increasingly confronted with a series of contradictory trends to maintain political control and legitimacy of the current regime and strengthening national security. First, expanding coal investment falls short of ensuring a favorable operating environment for business incumbents. Second, coal is not the most viable technology for maximizing jobs and creating a favorable working environment for blue-collar workers. Third, the ongoing dependence of Turkey on coal is facing intensified public resistance due to vulnerabilities from the technology. We briefly elaborate on these factors below.

\section{Energy security}

Maintaining and strengthening energy security through the vision of scaling coal investments is contradictory to market realities. A liberalized market without significant disruption by subsidies, in which the investment decisions of private sector actors depend primarily on market dynamics, has the potential to alter Turkey's coal-dependent outlook.

\section{Private profit}

Expanding coal investment falls short of ensuring a favorable operating environment for business incumbents. This means that private sector vested interests and lobbyists focused on protecting coal-based industries are less influential than they are in countries with stronger historical legacies of incumbent private sector coal investors.

\section{Employment}

Coal continues to provide employment for a declining but still politically significant number of workers in some regions. Many of these non-unionized jobs remain, however, low paid and insecure. The longer term social and economic challenges facing coal dependent workers and communities will require well planned, adequately financed strategies enabling a just and orderly transition to new sources of employment. Proactive and well-integrated regional economic 
transition strategies will also be an essential foundation for securing the economic and employment future of agricultural workers.

\section{Political power}

The ongoing dependence of Turkey on coal is facing intensified public resistance due to vulnerabilities from the technology. Citizen support for transitioning away from coal and opposing new coal mines and plants is likely to continue due to concerns about climate change, health impacts of air pollution, vulnerability and poor working conditions of coal workers and coal-dependent communities, concerns from the agricultural sector and impact on natural habitats.

To conclude, the debate about the future of coal plants and mines in Turkey remains controversial and contested due to ongoing tensions between the objectives of strengthening national energy and economic security on the one hand and on the other of maintaining the political legitimacy and control of the current regime. Further research is needed to strengthen understanding of factors with the potential to create a more favorable environment for lowcarbon technologies consistent with goal of maintaining political legitimacy. A thorough analysis to assess the role of regional political, business and societal actors in decisions regarding the energy sector is also needed. Further research is also needed to explore how employment matters in political power and elections in Turkey. Finally, it will be important to strengthen understanding of the extent to which action to address equity and justice concerns will be important in facilitating an accelerated transition away from coal in Turkey.

\section{Acknowledgments}

We would like to thank Professor Fiona Haines, the anonymous reviewers and the editors for helpful comments and discussions.

\section{Appendix}

This chapter contains supplementary online material at www.mcc-berlin.net/ pecoal/ch09.

\section{References}

Acar, S. and E. Yeldan (2015). Environmental impacts of coal subsidies in Turkey: a regional general equilibrium analysis. Energy Policy, 90, 1-15.

Acar, S., Kitson, L., Bridle, R. (2015). Subsidies to Coal and Renewable Energy in Turkey, International Institute for Sustainable Development, retrieved from www. iisd.org/gsi/sites/default/files/ffsandrens_turkey_coal_eng.pdf on 09.12.202.

Adaman, F., Arsel, M. and Akbulut, B. (2017). Conclusion: Neoliberal modernisation cast in concrete. In F. Adaman, B. Akbulut \& M. Arsel (Eds.). Neoliberal Turkey and its 
Discontents: Economic Policy and the Environment Under Erdogan. London: Bloomsbury Publishing, pp. 246-253.

Algedik, Ö. (2015). Financing Coal-High Carbon Arithmetic of Turkey, retrieved from www.onderalgedik.com/2015/05/05/financing-coal/ on 04/01/2021.

Algedik, Ö. (2017). Coal and Climate Change 2017, retrieved from www.onderalgedik. com/2017/09/10/coal-2017/ on 04/01/2021.

Aşık, G. (2014). Madencilik Sektoru: Cocuk Isciler, Hukuk ve Istatistikler TEPAV Policy Brief. Ankara, TEPAV.

Ateş, L. and Acar, S. (2020). “Tax expenditures for renewable energy in Turkey, In Patricia Alderete, Marcos Maximiliano Cáceres Falkiewicz, Rodolfo Rubén Salassa Boix (Eds.). Tributación ambiental y energías renovables en Argentina, Córdoba: Advocatus, ISBN 978-987-551-414-0, 581-606.

Avşaroğlu, N. (2018). Madencilik Sektoru, Istihdam ve Issizlik, retrieved from www.researchgate.net/publication/323267778_MADENCILIK_SEKTORU_ ISTIHDAM_ve_ISSIZLIK on 09.12.2020.

Bloomberg New Energy Finance (2019). New Energy Outlook, Bloomberg New Energy Finance. https://about.bnef.com/new-energy-outlook/.

Bridge, G., Özkaynak, B., \& Turhan, E. (2018). Energy Infrastructure and the fate of the nation: introduction to special issue. Energy Research E Social Science, 41, 1-11.

Çarkoğlu, A. (2017). Environmental concerns in Turkey: a comparative perspective. In F. Adaman, B. Akbulut \& M. Arsel (Eds.). Neoliberal Turkey and its Discontents: Economic Policy and Environment Under Erdoğan. London: Bloomsbury Publishing. pp. 147-174.

Climate Action Tracker (2015). Turkey Assessment, retrieved from https://climateaction tracker.org/media/documents/2018/4/CAT_2015-10-22_CountryAssessment_ Turkey.pdf on 18.09.2020.

Climate Analytics (n.d). Coal Phase-Out, retrieved from https://climateanalytics.org/ briefings/coal-phase-out/ on 18.09.2020.

Day, T., et al. (2016). Co-benefits of Climate Action: Assessing Turkey's Climate Pledge, Iklim Ağ1, New Climate Institute and Climate Action Network, retrieved from https://newclimate.org/wp-content/uploads/2016/10/benefits_of_climate_action _turkey.pdf on 04/01.2021.

Dorband, I. I., Jakob, M., \& Steckel, J. C. (2020). Unraveling the political economy of coal: insights from Vietnam. Energy Policy, 147, 111860.

Doukas, A. and I. Gençsu (2018). G20 Coal Subsidies, Istanbul: Overseas Development Institute, retrieved from https://cdn.odi.org/media/documents/12752.pdf 02.10.2020.

Duman, İ., et al. (2013). Termik Santral Etkileri Uzman Raporu: Konya Kapalı Havzası, Turkish Foundation for Combating Soil Erosion (TEMA).

Electricity Market Regulatory Authority (2018). Electricity Market Capacity Mechanism Regulation (30307), retrieved from www.resmigazete.gov.tr/eskiler/ 2018/01/20180120-23.htm on 19.04.2021.

Electricity Market Regulatory Authority (2019). Electricity Market Development Report 2018, Electricity Market Regulatory Authority.

Environmental Justice Organizations, Liabilities and Trade Atlas (n.d) Environmental Conflicts in Turkey, retrieved from https://ejatlas.org/country/turkey?translate $=$ en on 23.3.2021.

Euracoal (n.d). Turkey Country Profile, retrieved from https://euracoal.eu/info/coun try-profiles/turkey/ on 03.05.2021. 
Europe Beyond Coal (2020). EÜAȘ: A Briefing for Investors, Insurers and Banks, retrieved from https://beyond-coal.eu/wp-content/uploads/2020/03/EBC_EU AS_briefing-paper.pdf on 19.04.2021.

Foundation for Political, Economic and Social Research (2019). 5 Soru: Türkiye'nin Milli Enerji Serüveni, retrieved from www.setav.org/5-soru-turkiyenin-milli-enerjiseruveni/ on 03.05.2021.

Global Business Reports (2018) Turkey's 21st Century Coal Rush, retrieved from www. gbreports.com/article/turkeys-21st-century-coal-rush on 18.03.2021.

Global Energy Monitor (n.d) Opposition to Coal in Turkey, retrieved from www.gem. wiki/Opposition_to_coal_in_Turkey on 27.04.2021.

Global Energy Monitor, Sierra Club, CREA, Climate Risk Horizons, GreenID and Ekosfer (2021). Boom and Bust 2021: Tracking the Global Coal Plant Pipeline, retrieved from https://globalenergymonitor.org/wp-content/uploads/2021/04/ BoomAndBust_2021_final.pdf on 26.04.2021.

Greenpeace Mediterenean (2020). Air Quality Measurement Report of Afsin Elbistan A and B Region Kahramanmaras.

Greenpeace Mediterenean (2020). Eskişehir'de Danıştay’ın Kararı: Kamu Yararı Tarımın Korunmasıdır, retrieved from www.greenpeace.org/turkey/blog/eskisehirdedanistayin-karari-kamu-yarari-tarimin-korunmasidir/ on 03.04.2021.

Gümüşel, D. (2014). The Unpaid Health Bill, How Coal Plants in Turkey Make Us Sick. Brussels, Health and Environment Alliance.

Gümüşel, D. and Gündüzyeli, E. (2019). The Real Costs of Coal Mugla, Climate Action Network.

Gündoğan, A. C. (2017). Turkiye Sera Gazi Emisyon Istatistiklerine Yakın Bakıs, retrieved from www.iklimhaber.org/turkiye-sera-gazi-emisyon-istatistiklerineyakin-bakis/ on 20.04.2020.

Health and Environment Alliance (2018). Coal Power Generation and Health in Three Regions of Turkey; Çanakkale, İzmir and Tekirdağ.

Iklim Haber and KONDA (2018).Turkiye'de Iklim DeğişikliğiAlgısı ve Enerji Tercihleri Araştırmas1, retrieved from www.iklimhaber.org/wp-content/uploads/2018/06/ Tu\%CC\%88rkiyede-I\%CC\%87klim-Deg\%CC\%86is\%CC\%A7iklig\%CC\%86iAlg\%C4\%B1s\%C4\%B1.pdf on 27.04.2021.

International Energy Agency (IEA) (2021) Turkey 2021 Energy Policy Review, retrieved from www.iea.org/reports/turkey-2021 on 03.05.2021.

International Labour Organization Office for Turkey (2016). Contractual Arrangements in Turkey's Coal Mines: Forms, Extents, Drivers, Legal Drivers and Impact on OSH, retrieved from www.ilo.org/wcmsp5/groups/public/---europe/---ro-geneva/--ilo-ankara/documents/publication/wcms_458144.pdf on 27.04.2021.

Jakob, M., Flachsland, C., Steckel, J.C., (2020). Actors, objectives, context: a framework of the political economy of energy and climate policy applied to India, Indonesia, and Vietnam. Energy Research \& Social Science 70 (101775).

Kurçaloğlu, D. B. (2019). Turkish Power Markets [PowerPoint slides]. ENGIE Global energy management solutions.

Mining and Petroleum Affairs (n.d) Workplace and Employee Numbers in Hard coal and Lignite Sectors, retrieved from http://mapeg.gov.tr/maden_istatistik.aspx on 18.3.2021.

Ministry of Economy General Directorate of Incentive Implementation and Foreign Investment (2013). Investment in Turkey.

Ministry of Energy and Natural Resources (2019). 2019-2023 Strategic Plan. 
Ministry of Energy and Natural Resources (2019). Investor's Guide for Electricity Sector in Turkey, Ministry of Energy and Natural Resources.

Ministry of Environment and Urbanization (2020). Bakan Kurum'dan Kapatılan Termik Santrallerle İlgili Açıklama, retrieved from https://csb.gov.tr/bakan-kurum-dankapatilan-termik-santraller-ile-ilgili-aciklama-bakanlik-faaliyetleri-29763.

Myllyvirta, L. (2014). Silent Killers: Why Turkey Must Replace Coal Power Projects with Green Ener.

Myllyvirta, L., and Chuwah, C. (2018). Eskişehir'de Termik Santral Tehlikesi, Planlanan Alpu termik santralinin hava kalitesi ve sağlık üzerindeki etkileri, Istanbul: Greenpeace Mediterenean.

Organisation for Economic Co-operation and Development (2019). Environmental Performance Review: Turkey 2019, Organisation for Economic Co-operation and Development.

Oxford Business Group (2015). The Report: Turkey 2015, retrieved from https://oxfo rdbusinessgroup.com/overview/turkeys-construction-sector-maintain-its-signific ant-role-economy-several-large-projects-under-way on 26.04.2021.

Özluer, F., Erdem, C. U, Yıldırım, H. and Sakin, E. (2018) Iklim Adaleti icin Davalar Raporu 2017-2018, Ekoloji Kolektifi Dernegi.

Paker, H. (2017). The 'politics of serving' and neoliberal developmentalism: the megaprojects of the AKP as tools of hegemony building. In F. Adaman, B. Akbulut \& M.Arsel (Eds.). Neoliberal Turkey and Its Discontents: Economic Policy and the Environment Under Erdoğan. London: Bloomsbury Publishing, pp. 103-119.

Presidency of the Republic of Turkey Investment Office (2018). Energy Industry Report, retrieved from www.invest.gov.tr/en/sectors/pages/energy.aspx on 17.11.2020.

Richert, J. (2016). Great Potential, Missing Will, Istanbul: Institute for Advanced Sustainability Studies.

Right to Clean Air Platform (2020). Dark Report 2020: Air Pollution and its Health Impacts, retrieved from www.temizhavahakki.com/wp-content/uploads/2020/09/ Kara-Rapor-2020-Son27082020.pdf on 06.01.2021.

Şahin, Ü.,Aşıc1, A.A., Acar, S., Gedikkaya- Bal, P., Karababa,A.O., Kurnaz, L. (2016). Coal Report:Turkey's Coal Policies Related to Climate Change, Istanbul: Economy and Health, Sabanc1 University Istanbul Policy Center.

Shearer, C., Myllyvirta, L., Yu. A., Aitken, G., Mathew-Shah, N., Dallos, G., Nace, T. (2020). Boom and Bust 2020: Tracking the Global Coal Plant Pipeline, Global Energy Monitor, Sierra Club, Greenpeace International, Centre for Research on Energy and Clean Air.

Stake, R. (1995). The Art of Case Study Research. London, New Delhi, Sage Publications. TMMOB Union of Chambers of Turkish Engineers and Architects (2018). Air Pollution Report 2018, retrieved from www.cmo.org.tr/genel/bizden_detay.php?kod= 100058\&tipi $=91 \&$ sube $=0$ on 04.01.2021.

Turhan, E., Özkaynak, B., \& Aydın, C. İ. (2019). Coal, ash, and other tales: the making and remaking of the anti-coal movement in Aliağa, Turkey. Transforming Socio-Natures in Turkey. Oxfordshire: Taylor \& Francis.

Turkish Electricity Transmission Company (2020). Installed Capacity Data, retrieved from www.teias.gov.tr/tr-TR/.

Turkish Foundation for Combatting Soil Erosion (TEMA) (2013). Termik Santral Etkileri Uzman Raporu: Konya Kapali Havzasi, Turkish Foundation for Combating Soil Erosion.

Turkish Statistical Institute (2018). Greenhouse Gas Emissions Statistics 2016, Turkish Statistical Institute. 